\title{
The influence of existing activities around public spaces on the selection of location and type of street vendors' business. Case study: Tegallega Park, Bandung, West Java
}

\author{
I. Sudarisman, M.B. Mustafa, M.H.B.M. Isa \\ Universiti Sains Malaysia, Penang, Malaysia \\ H.F.S. Rusyda \\ Telkom University, Bandung, Indonesia
}

\begin{abstract}
The presence of street vendors who use public spaces as places of activity has caused various problems. Tegallega Park as a public space in the form of a park is also affected due to the presence of street vendors in it. This study aims to see and understand the relationship between activities around the park and the location selection and type of goods that are traded by street vendors. The research was conducted using a qualitative descriptive method. Data collection was carried out by observation and field documentation. Based on the results of the study, it was found that the level of crowd, type of activity, needs of the community, and goods traded around the park had an effect on the choice of location and goods sold by street vendors. This understanding can be used as a basis for consideration in planning public spaces.
\end{abstract}

Keywords: Tegallega Parks, existing activities, street vendors

\section{INTRODUCTION}

The number of migrants moving to the city driven by the need for better jobs and income cannot be matched by the growth of formal sector employment in the destination city. This condition causes migrants to find alternative employment or other sources of income to meet their daily needs through the informal economy. One form of the informal economy is street vendors. This phenomenon occurs in major cities in Indonesia, including Bandung.

Bandung as a big city that continues to grow has a great attraction for newcomers, so the growth in the number of street vendors also experiences a high increase. The number of street vendors in the city of Bandung in 2015 based on data from "Bappeda" reached 22,359 traders (Nugraha Ginanjar 2016).

McGee and Yeung (1977) mentioned that "hawkers as those people who offer goods or services for sale from public spaces, primarily streets and pavements". Siti Salamah \& Luthfi Muta'ali (2019) stated that "street vendors generally grow and occupy strategic locations such as trading areas, residential areas, education areas and other public facilities that create attractiveness. These street vendors violate existing regulations because they grow in public spaces that can interfere with public activities, change the function of public spaces, and create a slum impression."

The street vendors use public spaces as a place to run their business. One of the public spaces that are favorite places is a city park.

\subsection{Tegallega Park}

Tegallega Park has a land area of $19.65 \mathrm{Ha}$ (Muhammad Ramadhan \& Pranggono 2018). Tegallega Park is used for various activities such as sports, playing, relaxing, ceremonies, night markets, 
music performances, and others by residents and the city government of Bandung. Tegallega Park in the center of Bandung has a strategic location, namely the main city road that connects the residential area with the city center and is surrounded by a variety of activities. This condition causes street vendors in large numbers to carry out their activities in Tegallega Park.

\subsection{Street vendors and Tegallega Park problems}

Street vendors occupy areas both inside and outside Tegallega Park. In carrying out their activities they tend to be in groups and can be differentiated based on the type of goods sold or the services they offer. The problem arose because Tegallega Park was not designed to facilitate their activities. Street vendors use various areas or facilities whose function is not to facilitate their activities. These problems cause a decrease in the physical condition of the park and discomfort for other park users, especially in the areas used by street vendors.

This study aims to see whether there is a relationship between existing activities outside the park with the location selection of street vendors to carry out their activities. This study also aims to look at the relationship between the types of existing activities with the types of merchandise and services offered by street vendors. Through this relationship, it is hoped that the consideration of street vendors in choosing a location and determining the types of goods or services they offer can be understood. The results of this study can be used as a basis for consideration of planning and designing public spaces such as parks in the city of Bandung. Planning a public space in the form of a park in the future is expected to consider the existence of street vendors as part of it and facilitate their needs, so that current public space problems due to the presence of street vendors can be anticipated.

\section{RESEARCH METHODS}

This research was conducted with a qualitative descriptive method, trying to understand a phenomenon experienced by researchers in this case is the behavior of street vendors in carrying out their activities in Tegallega Park and explaining it in words (Setyowati 2011). According to Sugiyono in Setyowati (2011), qualitative research uses a "social situation" which consists of three elements, namely: place, actors, and activities that interact synergistically.

This research was conducted by direct observation and data collection in the field of existing activities outside the park, as well as the location that was chosen by street vendors in conducting their commercial activities. Observations and data collection were also carried out on the types of goods traded and services offered by street vendors at each location in Tegallega Park. Then analysis and conclusions are drawn from the results of the field data to see the relationships that occur.

\section{RESULTS AND DISCUSSION}

\subsection{Relationship between activities around the park and the location selection of street vendors}

Tegallega Park is located in the southern part of Bandung city. The location of the park is flanked by roads connecting the southern area of the city with the city center. Tegallega Park in the east is bordered by Mohammad Toha Road, the western part is bordered by Otto Iskandardinata, and the south is bordered by the BKR road. Jalan Otto Iskandardinata is a road that connects Tegallega Park with the famous shopping center in Bandung, namely "Pasar Baru" and is a route for Bandung citizens returning to work or traveling from the city center. This road is passed by two kinds of mass public transportation, namely "angkot" (a vehicle that can accommodate 12 passengers) and city buses. On the west side of the park next to Otto Iskandardinata Street, there is a public transportation stop. Jalan Mohammad Toha is a route for city residents who will travel or work to the city center. 


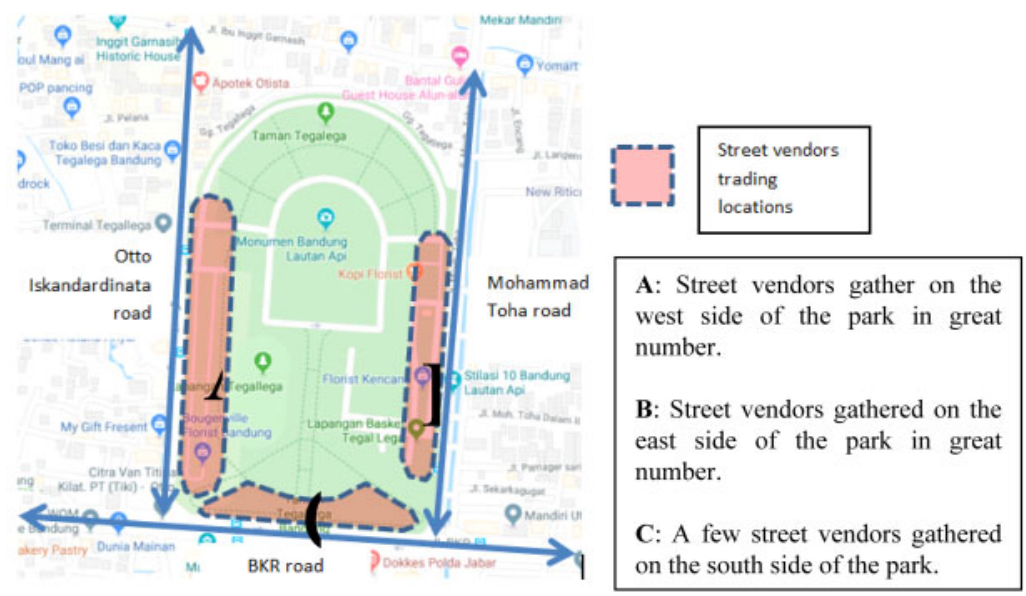

Figure 1. Map of Tegallega park, the road that borders the park area and the location of street vendors. (Source: Google maps \& personal analysis).

Public transportation is "angkot" and buses via this road. On the eastern side of the park adjacent to Jalan Mohammad Toha there is a public transportation stop. Meanwhile, the BKR road is the main street of the city of Bandung, which serves as a gateway to the city for immigrants from outside the city of Bandung. This road is traversed by "angkot" and buses. There is also a public transportation stop in the part of the park next to this road. The three roads are very congested every day because many private vehicles, public vehicles, and pedestrians pass them so that congestion often occurs, especially during the hours of leaving for work (6-8 in the morning) and returning from work (4-6 in the afternoon).

The park area in the East and West is the area most densely occupied by street vendors because it is busy with the movement of vehicles and people, so the possibility of interaction between large traders and potential buyers occurs. In the southern area, there are not too many street vendors because this area is an area that is prohibited from being used as a place to sell by the city government. In that area, officers are stationed to keep it free from street vendors.

\subsection{Relationship between activities around the park and the type of goods that are traded by street vendors}

Types of street vendors who carry out business activities in Tegallega Park are grouped based on the goods sold or the services offered, namely:

- raw material traders: sell raw food ingredients for household needs such as vegetables, fruits, meat, fish, and cooking spices;

- food and beverage traders: sell ready-to-consume food and beverages;

- grocery dealer: sells household items;

- fashion traders: selling clothes, shoes, and accessories;

- electronics trader: sells a variety of electronic equipment;

- mixed trader: sells house decorations/decorations, toys, and others (family and home needs);

- sports equipment rental services: rent sports equipment;

- children's game rental services; renting out children's play services; and

- medical services: selling drugs and conducting medical therapy.

In the road section of Mohammad Toha, various activities that take place are household activities (residential areas), educational activities (school areas), and work activities (private and government office areas). In the eastern part of the park which is adjacent to Jalan Mohammad Toha, street 

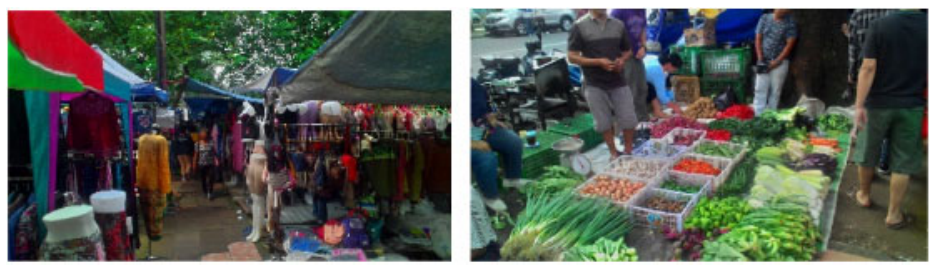

Figure 2. Street vendors in the eastern part of Tegallega Park. (Source: personal).
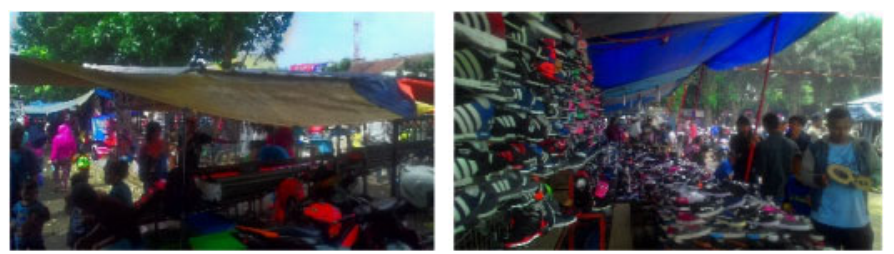

Figure 3. Street vendors in the western part of Tegallega Park. (Source: personal)

vendors gather and carry out their business activities around the park entrance. In addition, street vendors also gather in areas outside the park, namely along the pedestrian paths and along the roadside of motorized vehicles from Jalan Mohammad Toha. The street vendors selling in this area are dominated by raw material traders, food and beverage traders, grocery merchants, fashion traders, and mixed traders.

Based on observations and analysis, street vendors who are in the eastern area of the park choose the type of merchandise that is suitable or needed by the actors in the surrounding activities, such as providing for families, school children, and office employees.

On the road section of Otto Iskandardinata, the various activities that take place are household activities (residential areas) and commercial activities (shop and shop areas). This section of the road is known as a shopping area, and the famous shopping center in the area is "Pasar Baru". In the west part of the park which is adjacent to Otto Iskandardinata Street, street vendors gather and carry out their business activities around the park entrance. Also, street vendors gather in areas outside the park, namely along the pedestrian paths and along the roadside of motorized vehicles from Jalan Otto Iskandardinata. Street vendors selling in this area are dominated by food and beverage traders and fashion traders.

Based on observations and analysis, street vendors who are in the western part of the park choose the type of merchandise that is suitable or needed by the actors in the surrounding activities, such as providing for the needs of shoppers and shop employees in the Otto Iskandardinata area. In addition, street vendors also sell items that are similar or complementary to those sold in shops (the types of goods sold in shops are mostly fashion items) along Otto Iskandardinata Street, but at a more affordable price.

In the BKR road section, various activities that take place are household activities (residential areas), work activities (private and government office areas), and educational tourism activities (museums). In the southern part of the park which is adjacent to Jalan BKR, street vendors gather and carry out their business activities outside the park along the pedestrian path from Jalan BKR. The street vendors selling in this area are dominated by food and beverage traders.

Based on observations and analysis, street vendors who are in the southern part of the park choose the type of merchandise that is suitable or needed by the activity actors in the vicinity, such as office employees, pedestrians, and motorized vehicle users passing on the BKR road.

In the area south of the park, there are not many street vendors selling because this area has been designated by the city government as a prohibited area for street vendors to occupy. Apart from that, the municipal police officers, "Satpol PP", are assigned to guard the area so that there are few 

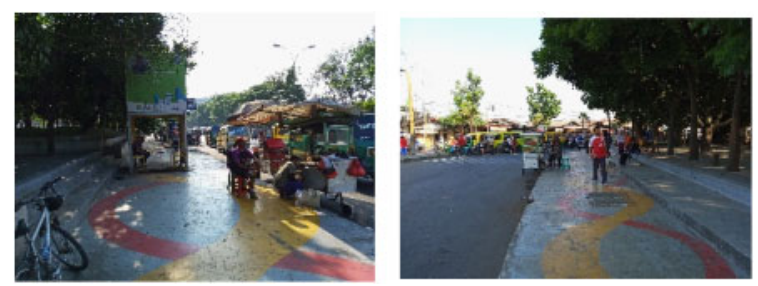

Figure 4. Street vendors in the southern part of Tegallega Park. (Source: personal).

street vendors, they do not sell various types of goods, and they only occupy the pedestrian lane outside the park.

\section{CONCLUSION}

Based on the above analysis, street vendors choose a place to run their business based on several considerations:

- There is a high movement of people or vehicles, allowing interaction with potential buyers.

- There are large associations of people who carry out various activities.

- Government regulations governing an area and the presence of officers in that place.

Meanwhile, in determining the types of goods sold or services offered by street vendors, consider the following:

- The type of activity that takes place around the area is chosen as the place to run the business.

- The needs of people who are active in the area where the business is located.

- Types of goods sold in commercial areas (shop houses and shops) adjacent to the place of business. Goods that are sold are usually more of a trap or the same but at a more affordable price.

The existence of public spaces in the city of Bandung today cannot be separated from the presence of street vendors in it. Therefore, public spaces also need to be designed to facilitate the needs of street vendors. Through understanding the considerations of street vendors in determining the location and type of business, the city government is expected to be able to make careful planning in making public spaces by considering the presence of street vendors as part of it in the future. It is hoped that this approach to public space planning can overcome problems in the public space faced in the city of Bandung today.

\section{REFERENCES}

McGee, T. G. and Yeung, Y. M. 1977. Hawkers in Southeast Asian cities: planning for the bazaar economy. Ottawa, IDRC.

Muhammad Ramadhan, E. and Pranggono, B. 2018. Transformation of Tegallega Park In Bandung City. Prosiding Perencanaan Wilayah dan Kota 4(2):331-341.

Nugraha Ginanjar, A. 2016. Gaya Kepemimpinan Walikota Menertibkan Pedagang Kaki Lima di Kota Bandung. Bandung: Program Studi Ilmu Pemerintahan Fakultas Ilmu Sosial dan Ilmu Politik Universitas Komputer Indonesia.

Salamah, S. and Muta'ali, L. Analisis Pemanfaatan Ruang Oleh Aktivitas Pedagang Kaki Lima (PKL) di Koridor Jalan Dipati Ukur Kota Bandung. Jurnal Bumi Indonesia 8(4).

Setyowati. 2011. Pengelolaan Pembelajaran IPS Terpadu Berbasis Kurikulum Tingkat Satuan Pendidikan (KTSP) (Studi Situs di SMP Negeri 1 Wonogiri). Surakarta: Program Pascasarjana Universitas Muhamadiyah Surakarta.

https://www.google.com/maps/search/taman+tegallega/@6.9349232,107.6023988,17z/data=!3m1!4b1 